\title{
5. MINERALOGY AND ISOTOPIC COMPOSITION OF SULFUR IN LAYER 3 GABBROS FROM THE INDIAN OCEAN, HOLE 735B ${ }^{1}$
}

\author{
Jeffrey C. Alt ${ }^{2}$ and Thomas F. Anderson ${ }^{3}$
}

\begin{abstract}
Sulfide mineralogy, sulfur contents, and sulfur isotopic compositions were determined for samples from the $500-\mathrm{m}$ gabbroic section of Ocean Drilling Program Hole 735B in the southwest Indian Ocean. Igneous sulfides (pyrrhotite, chalcopyrite, pentlandite, and troilite) formed by accumulation of immiscible sulfide droplets and crystallization from intercumulus liquids. Primary sulfur contents average around $600 \mathrm{ppm}$, with a mean sulfide $\delta^{34} \mathrm{~S}$ value near $0 \%$, similar to the isotopic composition of sulfur in mid-ocean ridge basalt glass. Rocks from a 48 -m interval of oxide gabbros have much higher sulfur contents (1090-2530 ppm S) due to the increased solubility of sulfur in Fe-rich melts. Rocks that were locally affected by early dynamothermal metamorphism (e.g., the upper 40 $\mathrm{m}$ of the core) have lost sulfur, averaging only $90 \mathrm{ppm} \mathrm{S}$. Samples from the upper $200 \mathrm{~m}$ of the core, which underwent subsequent hydrothermal alteration, also lost sulfur and contain an average of $300 \mathrm{ppm}$ S. Monosulfide minerals in some of the latter have elevated $\delta^{34} \mathrm{~S}$ values (up to $+6.9 \%$ ), suggesting local incorporation of seawater-derived sulfur. Secondary sulfides (pyrrhotite, chalcopyrite, pentlandite, troilite, and pyrite) are ubiquitous in trace amounts throughout the core, particularly in altered olivine and in green amphibole. Pyrite also locally replaces igneous pyrrhotite. Rocks containing secondary pyrite associated with late low-temperature smectitic alteration have low $\delta^{34} \mathrm{~S}$ values for pyrite sulfur (to $-16.6 \%$ ). These low values are attributed to isotopic fractionation produced during partial oxidation of igneous sulfides by cold seawater. The rocks contain small amounts of soluble sulfate ( $6 \%$ of total $\mathrm{S})$, which is composed of variable proportions of seawater sulfate and oxidized igneous sulfur. The ultimate effect of secondary processes on layer 3 gabbros is a loss of sulfur to hydrothermal fluids, with little or no net change in $\delta^{34} \mathrm{~S}$.
\end{abstract}

\section{INTRODUCTION}

Reaction of seawater with the oceanic crust influences the concentrations of many elements in the oceans and has been suggested to affect the mass and isotopic composition of sulfur in seawater (Edmond et al., 1979). Subduction of altered crust may contribute to the ${ }^{34} \mathrm{~S}$-enrichment of igneous rocks in island arcs (Sasaki and Ishihara, 1979; Ueda and Sakai, 1984; Woodhead et al., 1987) and to sulfur isotopic heterogeneities in the mantle (Chaussidon et al., 1987; Harmon et al., 1987). Studies documenting the distribution and isotopic composition of sulfur in the upper oceanic crust (volcanics and dikes of oceanic layer 2) have been published (Andrews, 1979; Hubberten, 1983; Field et al., 1984; Alt et al., 1989), but little is known about the geochemistry of sulfur in gabbros of oceanic layer 3 . The $500 \mathrm{~m}$ of gabbros penetrated by Hole 735B during Leg 118 provide an excellent continuous section through a portion of layer 3. This study presents the mineralogy of sulfides, whole-rock sulfur contents and sulfur isotopic compositions of gabbros from Hole 735B, with the goals of (1) understanding the geochemistry of sulfur in the lower oceanic crust and (2) providing some preliminary constraints on the role that layer 3 plays in cycling of sulfur in the oceans and in subduction zones.

\section{SITE 735}

Site 735 is located on the eastern rim of the Atlantis II Fracture Zone in the Indian Ocean (Fig. 1). The site is on an uplifted block, $5 \times 2 \mathrm{~km}$ in size, in about $700 \mathrm{~m}$ of water.

\footnotetext{
${ }^{1}$ Von Herzen, R. P., Robinson, P. T., et al., 1991. Proc. ODP, Sci. Results, 118: College Station, TX (Ocean Drilling Program).

2 The University of Michigan Department of Geological Sciences, 1006 C.C. Little Building, Ann Arbor, MI 48109-1063, U.S.A.

${ }^{3}$ Department of Geology, University of Illinois, Urbana, IL 61801, U.S.A.
}

Drilling at Hole 735B penetrated $500.7 \mathrm{~m}$ of gabbroic rocks, with a total recovery of $87 \%$. Six major lithologic units were defined by shipboard scientists, primarily on the basis of igneous mineralogy, mineral compositions, and deformation features (Shipboard Scientific Party, 1989; Dick et al., this volume; Fig. 2).

Lithologic Unit $I$ is a 37.4-m-thick sequence of foliated metagabbro (gabbronorite and olivine gabbro). Igneous textures have been completely destroyed, and the rocks consist mostly of neoblasts of plagioclase, clinopyroxene, and brown amphibole. Unit II comprises $132.75 \mathrm{~m}$ of olivine gabbro and olivine-bearing gabbro. Most of the rocks are mesocumulates and chemically are fairly primitive. Thin layers rich in $\mathrm{Fe}-\mathrm{Ti}$ oxides are common, however, often associated with zones of deformation. Unit III is a 53.35-m-thick section of oxidebearing olivine gabbro with intervals of oxide gabbro. The section is similar to Unit II, but the rocks are chemically more evolved. Unit IV consists of $50.49 \mathrm{~m}$ of oxide gabbros. These contain abundant opaque $\mathrm{Fe}$-Ti oxide minerals (5-25 vol\%) and have $\mathrm{Fe}_{2} \mathrm{O}_{3}{ }^{\mathrm{T}}$ contents ranging up to about $25 \mathrm{wt} \%$. Small amounts of olivine are also present in the rocks. Unit V is a $108.34-\mathrm{m}$ section of relatively uniform olivine gabbro. Most rocks are mesocumulates that are mineralogically and chemically similar to Unit II. Unit VI is a $118.30-\mathrm{m}$ interval of olivine-rich gabbro with abundant layers of troctolite. These gabbros are similar to Unit V, but are more olivine rich. The interlayered troctolites and troctolitic gabbros are the most mafic rocks encountered in the hole.

The gabbros are variably altered, with alteration related to local deformation and permeability. Several different stages and types of alteration have been recognized, including (1) early dynamothermal metamorphism, (2) brittle deformation and static metamorphism, and (3) low temperature alteration (Vanko and Stakes, this volume; Shipboard Scientific Party, 1989). An early stage of dynamothermal metamorphism pro- 


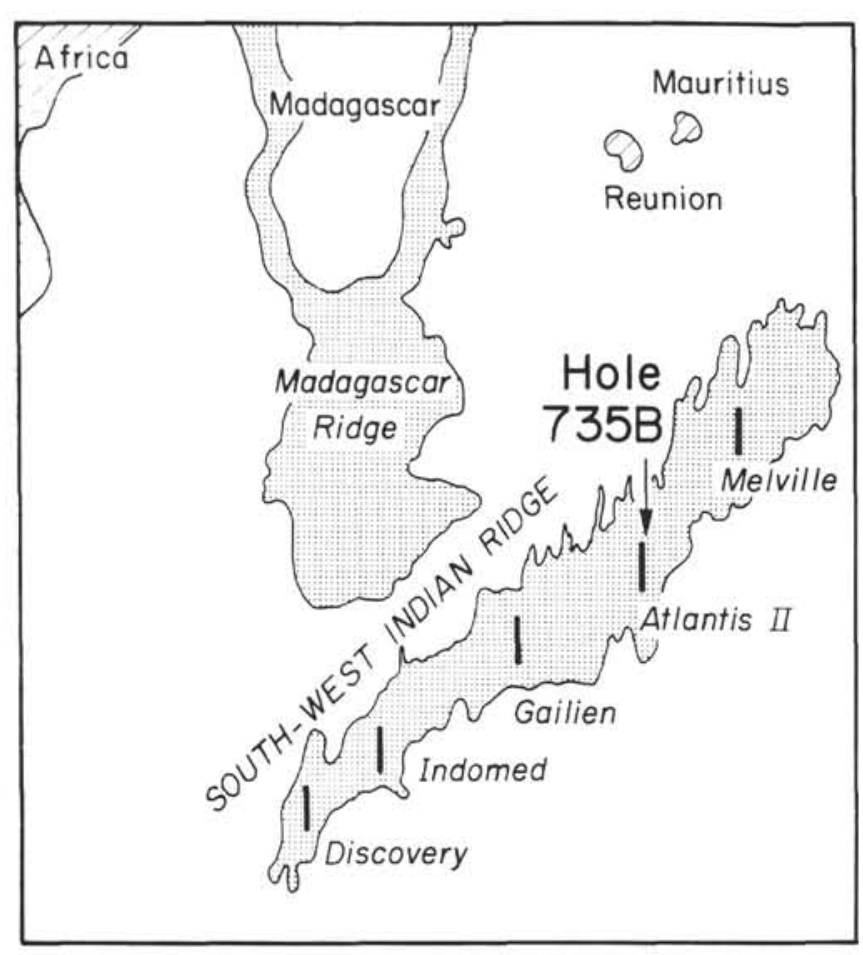

Figure 1. Map showing the location of Site 735 in the Indian Ocean. Major fracture zones indicated by heavy lines.

duced the highly foliated rocks that are characteristic of Unit I. Two other major zones of plastic deformation and metamorphism occur from 250 to $275 \mathrm{~m}$ and from 430 to $498 \mathrm{~m}$. Temperatures of metamorphism derived from mineral chemi$\mathrm{cal}$ and oxygen isotopic compositions ranged from about $700^{\circ}$ to $600^{\circ} \mathrm{C}$ (Vanko and Stakes, this volume).

Dynamothermal metamorphism was followed by brittle deformation and penetration of seawater into the gabbros. This resulted in static alteration of undeformed gabbros and the formation of near-vertical veins filled mainly with hornblende and sodic plagioclase. Mineral compositions and oxygen isotopic data indicate temperatures of $500^{\circ}$ to $600^{\circ} \mathrm{C}$ for most of the hornblende-plagioclase veining (Vanko and Stakes, this volume). Pyroxene and plagioclase in the wall rock around veins and microcracks were also replaced by green amphibole and sodic plagioclase, respectively. Veins and fractures are most abundant in the upper $200 \mathrm{~m}$ of the core and are less common at greater depths. In addition to veins, three zones of brecciation occur around 180, 275, and $330 \mathrm{~m}$, where clinopyroxene, clinozoisite, sphene, actinolite, chlorite, and zeolites fill former open spaces. The mineral paragenesis, fluid inclusions and oxygen isotope ratios indicate decreasing temperatures of alteration in these zones, from amphibolite grade $\left(550^{\circ}-400^{\circ} \mathrm{C}\right)$ to greenschist $\left(<400^{\circ} \mathrm{C}\right)$ and lower temperatures (Vanko and Stakes, this volume). In undeformed rocks, static metamorphism is characterized by the formation of reaction "coronas" around igneous minerals and replacement by secondary $\mathrm{Mg}-\mathrm{Fe}$ amphibole, talc, phlogopite, pargasite, actinolite, and chlorite.

Evidence for low-temperature alteration is scattered throughout the core, and is most intense at 33 to $39 \mathrm{~m}$ and in the three brecciated zones (at around 180, 275, and $330 \mathrm{~m}$ ). Low-temperature alteration is characterized by smectite \pm Fe-oxyhydroxide \pm carbonate in veins, as pseudomorphs of olivine and orthopyroxene, and disseminated in the rocks.
This alteration is thought to be related to late circulation of cold seawater along permeable zones.

\section{METHODS}

Opaque minerals were studied, and whole-rock sulfur contents and sulfur isotopic compositions measured for 22 samples representative of the six different lithologic units. Minerals were identified and phase relationships determined by optical examination of polished thin sections in transmitted and reflected light. Chemical compositions of sulfide minerals were analyzed using a JEOL 733 electron microprobe. Operating conditions were the following: $15-\mathrm{kV}$ accelerating voltage; $30-\mathrm{nA}$ sample current; $1-\mu \mathrm{m}$ spot size; and $30-$ to $40-\mathrm{s}$ counting times. Sulfur and carbon contents of whole-rock powders were measured using a LECO CS-244 carbon-sulfur analyzer. Replicate analyses of samples were generally reproducible to within $10 \%$ of reported values for sulfur and to within $5 \%$ for carbon.

Various forms of sulfur were extracted from whole-rock powders for isotopic analysis using a stepwise technique modified from Puchelt and Hubberten (1979). In the first step, monosulfides (such as pyrrhotite, chalcopyrite, pentlandite, etc.) were decomposed by reaction with $6 \mathrm{~N} \mathrm{HCl}$ at $80^{\circ} \mathrm{C}$ for at least $1 \mathrm{hr}$ in a closed vessel, through which nitrogen continuously flowed. Zinc metal was added to reduce cuprous sulfides (Ueda and Sakai, 1984). Evolved $\mathrm{H}_{2} \mathrm{~S}$ was precipitated as $\mathrm{Ag}_{2} \mathrm{~S}$ by bubbling the $\mathrm{N}_{2}$ carrier gas through $\mathrm{AgNO}_{3}$ solution. Soluble sulfate extracted from the rock during this first stage was precipitated as $\mathrm{BaSO}_{4}$. Pyrite sulfur was extracted from the residue of the previous step by reaction with a $\mathrm{CrCl}_{2}-\mathrm{HCl}$ solution at $80^{\circ} \mathrm{C}$ in a stream of nitrogen (Canfield et al., 1986), and evolved $\mathrm{H}_{2} \mathrm{~S}$ was precipitated as $\mathrm{Ag}_{2} \mathrm{~S}$. Sulfur isotope ratios were measured on $\mathrm{SO}_{2}$ gas, which was produced from $\mathrm{Ag}_{2} \mathrm{~S}$ by combustion with $\mathrm{Cu}_{2} \mathrm{O}$, or from $\mathrm{BaSO}_{4}$ by combustion with sodium metaphosphate, at $950^{\circ} \mathrm{C}$ under vacuum. Data are reported as delta notation relative to Canyon Diablo troilite (CDT). Instrument uncertainty for individual measurements is $\pm 0.2 \%$, but reproducibility of replicate extractions and analyses is approximately $\pm 0.5 \%$.

\section{RESULTS}

\section{Opaque Mineral Petrology}

\section{Igneous Sulfides}

The predominant sulfide minerals in samples from Hole $735 \mathrm{~B}$ are igneous sulfides. These occur in most samples, but are particularly abundant in the oxide gabbros of Unit IV. However, the foliated metagabbros of Unit I contain only traces of igneous sulfides enclosed in relicts of primary silicates. Igneous sulfides are also relatively rare in Unit II, which contains more abundant veins and where the rocks are more extensively recrystallized than deeper in the core. The absence of igneous sulfides in these units is most likely due to the breakdown of these minerals along with igneous silicates during early dynamothermal metamorphism and later veinrelated hydrothermal metamorphism.

Igneous sulfides occur as irregular to round or oblong globular shapes, from tens to several hundreds of micrometers in size. They are typically enclosed in brown igneous amphibole surrounding pyroxenes or in interstitial areas between igneous minerals (Fig. 3). They are also present as inclusions within plagioclase and pyroxene (Fig. 3A). In the oxide gabbros of Unit IV, igneous sulfides occur as intergrowths with and inclusions in magnetite and ilmenite. In one sample (118-735B-68R-2, 20-24 $\mathrm{cm}$ ), igneous sulfide is partially enclosed in olivine and appears to be an intergrowth of sulfide and olivine. 


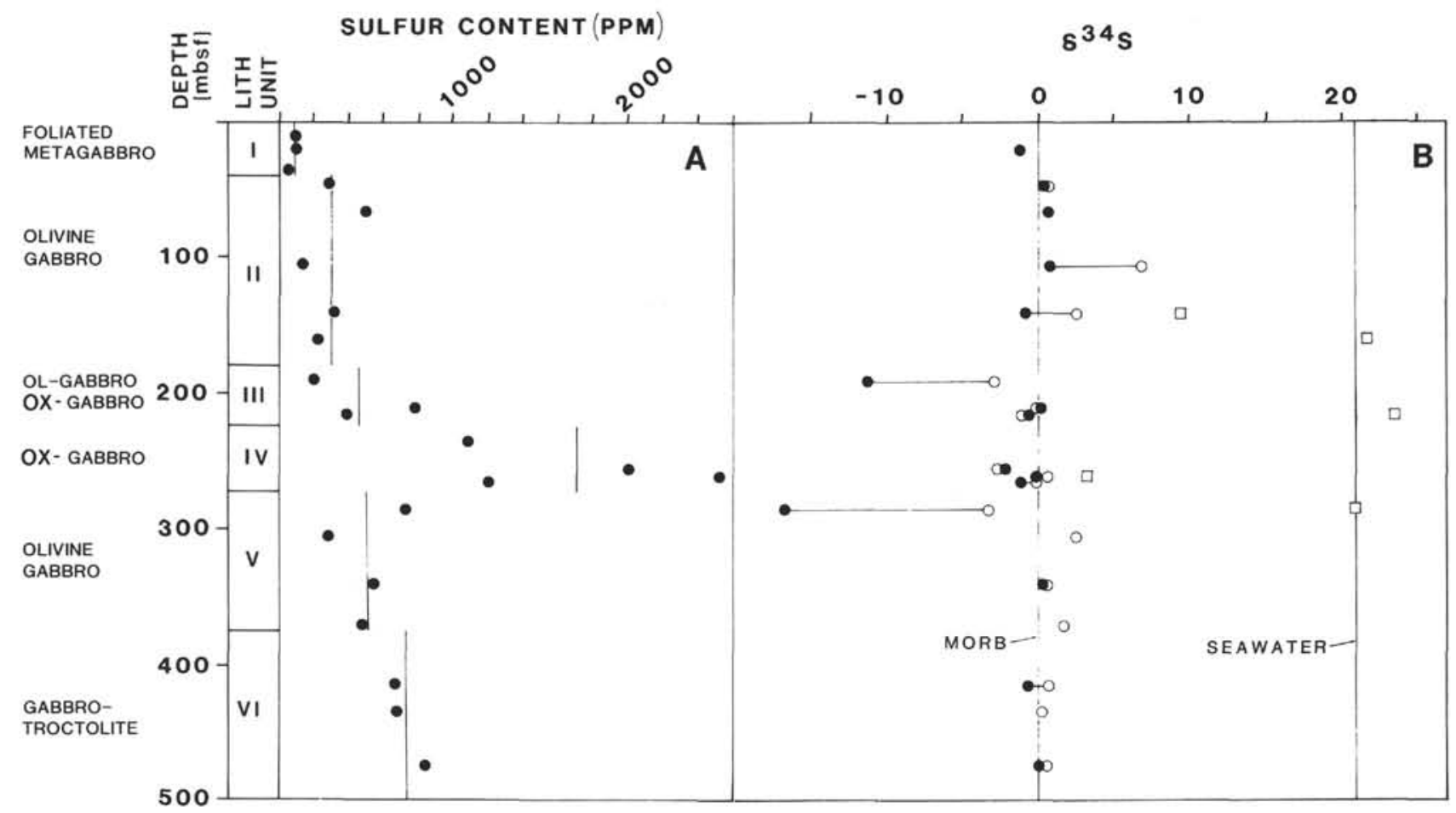

Figure 2. Sulfur data for Hole 735B. Lithostratigraphic column at left is explained in text. A. Whole-rock sulfur contents. Vertical lines are average values for individual lithostratigraphic units. B. Sulfur isotopic composition in per mil, CDT. Open circles = monosulfide sulfur; solid circles = pyrite sulfur; open squares = sulfate sulfur. Vertical lines indicate isotopic composition of sulfur in MORB glass and seawater (Sakai et al., 1984; Rees et al., 1978).

Pyrrhotite is the most common igneous sulfide mineral, followed by chalcopyrite, troilite, and pentlandite. The globular igneous sulfides are most commonly multiphase aggregates composed of pyrrhotite plus one or more of the other phases (Fig. 3B), but monomineralic grains of pyrrhotite and, less commonly, chalcopyrite occur. Small amounts of magnetite also are sometimes present. Troilite occurs in lenslike intergrowths with pyrrhotite in Units V and VI, and in one sample each from Units III and IV (Fig. 3B). The mineralogy and occurrence of igneous sulfides in Hole 735B are typical of igneous sulfides that separated and crystallized from basaltic liquids (Craig and Kullerud, 1969).

No consistent difference in mineralogy was observed between igneous sulfides included in silicate or $\mathrm{Fe}-\mathrm{Ti}$ oxide minerals and those in interstitial areas. Likewise, the mineralogy of igneous sulfides in Units II, III, V, and VI is essentially identical. The oxide gabbros of Unit IV, however, do not contain any pentlandite in igneous sulfide globules, nor was any secondary pentlandite observed in these samples.

Representative microprobe analyses of sulfides are given in Table 1. Igneous pyrrhotites contain 93.3 to $95.5 \mathrm{~mol} \% \mathrm{FeS}$, with nickel contents ranging up to $0.82 \mathrm{wt} \%$ and Co contents of up to $0.3 \%$. The highest Co contents and lowest Ni contents for pyrrhotite occur in the oxide gabbros of Unit IV. Where pyrrhotite coexists with troilite, the pyrrhotite has consistently higher Ni contents $(0.09-0.74 \%)$ than troilite $(<0.04 \%$ $\mathrm{Ni}$ ). Co contents of coexisting troilite and pyrrhotite are variable, but both are low $(<0.12 \%)$. Cooling of Fe-rich pyrrhotite $(>48$ atomic $\% \mathrm{Fe})$ to temperatures less than $140^{\circ} \mathrm{C}$ results in exsolution of troilite and hexagonal pyrrhotite (Kissin and Scott, 1982), giving rise to the textures observed in Figure 3B. The composition of pyrrhotite coexisting with troilite in Hole 735B samples (95.5 $\pm 0.7 \mathrm{~mol} \% \mathrm{FeS})$ is identical to the experimentally determined composition of hexagonal pyrrhotite of structural type $6 \mathrm{C}$, which is stable at temperatures less than about $80^{\circ} \mathrm{C}(95.6 \% \mathrm{FeS}$, Kissin and Scott, 1982).

Igneous pentlandites have compositions close to the intermediate $\mathrm{Fe}_{4.5} \mathrm{Ni}_{4.5} \mathrm{~S}_{8}$ formula, and contain minor amounts of Co $(1.09 \%-4.45 \%)$. All analyzed $\mathrm{Cu}-\mathrm{Fe}$ sulfides have stoichiometric chalcopyrite compositions (not shown in Table 1).

\section{Secondary Sulfides}

Secondary sulfides occur in trace amounts throughout the core: in olivine pseudomorphs, in recrystallized and interstitial areas, as pseudomorphs of igneous sulfides, and in small veinlets. Secondary sulfides are extremely rare, however, in the deformed metagabbros of Unit I. The most common occurrence of secondary sulfides is in the alteration coronas replacing olivine (Fig. 4A). Secondary sulfides also are sometimes present in similar alteration coronas around the margins of orthopyroxene. These alteration rims or coronas occur in all samples except the foliated metagabbros of Unit I and several samples of Unit IV oxide gabbros. There is a general zonation in the coronas from relict olivine outward to talc plus magnetite and then colorless amphibole plus magnetite. These zones are followed outward by green amphibole, chlorite, or phlogopite. This is a generalized zonation: one or several minerals of the sequence are often missing, and in many cases, the olivine has been totally replaced. Sulfides are common in small amounts with magnetite in the talc and/or colorless amphibole zones. Pyrrhotite is the most common sulfide, occurring as laths up to several tens of micrometers long, intergrown with magnetite and silicates (Fig. 4A). Chalcopyrite and pentlandite also occur, generally as individual grains or intergrown with magnetite, but multiphase grains of pyr- 

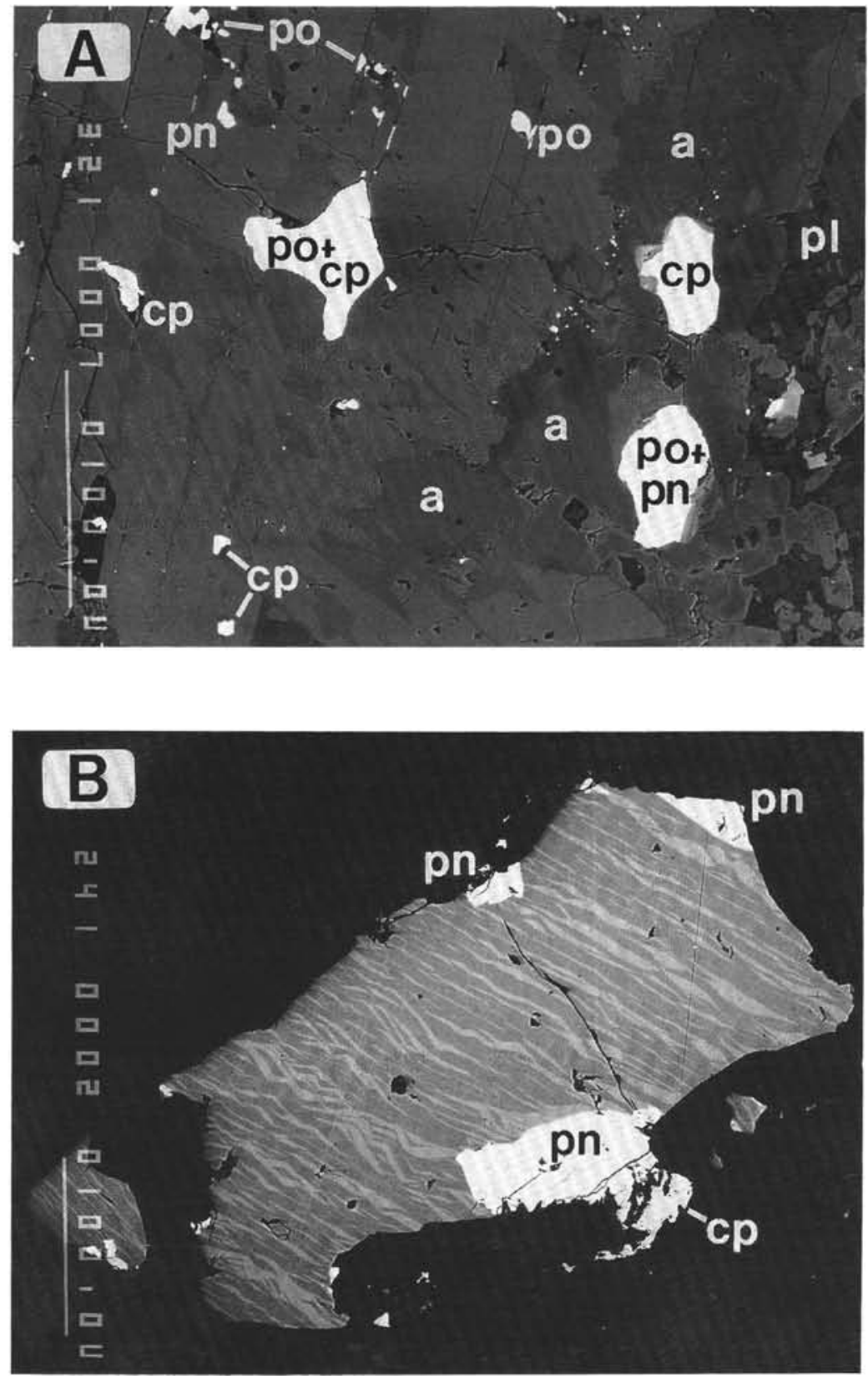

Figure 3. Backscattered electron photomicrographs of igneous sulfides in Hole 735B samples. Scale bars $=100 \mu \mathrm{m}$. A. Globular igneous sulfides (white) enclosed in pyroxene (lighter gray at left) and brown igneous amphibole (darker gray, a), which rims pyroxene and replaces pyroxene in patches. $\mathrm{Po}=$ pyrrhotite; $\mathrm{Pn}=$ pentlandite; $\mathrm{Cp}=$ chalcopyrite. Plagioclase (darkest gray $=\mathrm{Pl}$ ) present at right. Sample 118-735B-13R-2, 75-79 cm, microprobe analyses of pyrrhotite and pentlandite in Table 1. B. Pyrrhotite (light gray) with troilite exsolutions (darker gray), plus pentlandite and chalcopyrite. Sample 118-735B-81R-2, 100-104 cm, microprobe analyses of pentlandite and pyrrhotite plus exsolved troilite in Table 1.

rhotite \pm chalcopyrite \pm pentlandite are also observed. In some samples (from Units III, V, and VI), exsolutions of troilite are present in the secondary pyrrhotite. Pyrite occurs in a few samples throughout the core as a later pseudomorph of secondary pyrrhotite. Small fractures in the central olivine relics contain talc, magnetite and sometimes pyrrhotite (Fig. 4A). These microcracks can sometimes be traced into adja- cent plagioclase crystals, where they are delineated by trains of fluid inclusions along healed fractures in the plagioclase. In many samples the central olivine relic surrounded by an alteration corona is veined or partly replaced by a magnesian smectite \pm magnetite \pm pyrrhotite or pyrite. Carbonate and/or $\mathrm{Fe}$-oxyhydroxide is present and replaces the central olivine in some samples. 
Table 1. Representative electron microprobe analyses of sulfides.

\begin{tabular}{|c|c|c|c|c|c|c|c|c|}
\hline \multirow{2}{*}{$\begin{array}{l}\text { Lith. } \\
\text { unit }\end{array}$} & \multirow{2}{*}{$\begin{array}{l}\text { Core, section, } \\
\text { interval }(\mathrm{cm})\end{array}$} & \multirow[b]{2}{*}{ Type } & \multicolumn{6}{|c|}{ Elements (wt\%) } \\
\hline & & & $\mathrm{S}$ & $\mathrm{Fe}$ & $\mathrm{Ni}$ & $\mathrm{Cu}$ & Co & Total \\
\hline \multirow[t]{3}{*}{ I } & $118-735 \mathrm{~B}-13 \mathrm{R}-2,75-79$ & PO-1-I & 38.56 & 61.28 & 0.50 & - & 0.02 & 100.36 \\
\hline & & PN-1-I & 33.31 & 30.51 & 31.21 & - & 4.45 & 99.48 \\
\hline & & $\mathrm{PO}-2-\mathrm{OL}$ & 38.61 & 60.63 & 0.20 & - & 0.10 & 99.54 \\
\hline \multirow{2}{*}{ II } & $-34 \mathrm{R}-2,96-100$ & ML-2-AMPH & 35.80 & 0.96 & 62.34 & 0.12 & 0.13 & 99.35 \\
\hline & & PN-2-AMPH & 33.33 & 21.52 & 43.86 & 0.09 & 0.27 & 99.07 \\
\hline \multirow[t]{4}{*}{ III } & $-45 R-2,32-36$ & TR-1-I & 36.63 & 63.94 & 0.05 & 0.15 & 0.08 & 100.85 \\
\hline & & PO-1-I & 38.23 & 61.33 & 0.68 & - & - & 100.24 \\
\hline & & PN-1-I & 33.47 & 34.92 & 29.35 & 0.27 & 1.75 & 99.76 \\
\hline & & PO-2-OL & 36.43 & 63.47 & 0.07 & 0.06 & - & 100.03 \\
\hline \multirow[t]{2}{*}{ IV } & $-49 \mathrm{R}-2,118-122$ & PO-1-PL & 39.34 & 61.19 & 0.17 & - & 0.14 & 100.84 \\
\hline & & PY-2-PL & 52.45 & 46.26 & 1.17 & - & 0.39 & 100.27 \\
\hline \multirow[t]{2}{*}{ IV } & $-54 R, 37-41$ & TR-1-PL & 36.25 & 63.85 & 0.03 & 0.03 & 0.01 & 100.17 \\
\hline & & PO-1-PL & 38.75 & 61.43 & 0.12 & - & 0.12 & 100.42 \\
\hline \multirow[t]{5}{*}{ v } & $-68 R-2,20-24$ & TR-2-OL & 37.09 & 63.47 & 0.04 & 0.08 & 0.03 & 100.71 \\
\hline & & PO-2-OL & 37.72 & 62.69 & 0.25 & 0.03 & 0.06 & 100.75 \\
\hline & & PN-1-I & 33.81 & 34.31 & 29.96 & - & 2.65 & 100.73 \\
\hline & & TR-1-1 & 36.50 & 63.46 & 0.01 & - & - & 99.97 \\
\hline & & PO-1-I & 38.87 & 61.25 & 0.33 & 0.08 & 0.01 & 100.54 \\
\hline \multirow[t]{6}{*}{ VI } & $-81 \mathrm{R}-2,100-104$ & PN-2-OL & 33.33 & 29.16 & 26.67 & 0.38 & 9.89 & 99.43 \\
\hline & & TR-2-OL & 36.45 & 62.69 & 0.04 & 0.06 & 0.08 & 99.32 \\
\hline & & PO-2-OL & 38.46 & 60.49 & 0.32 & 0.02 & 0.01 & 99.30 \\
\hline & & TR-1-I & 35.93 & 63.10 & 0.01 & 0.01 & - & 99.05 \\
\hline & & PO-1-1 & 38.66 & 61.59 & 0.11 & 0.09 & - & 100.45 \\
\hline & & PN-1-I & 33.70 & 37.43 & 27.59 & 0.27 & 1.16 & 100.15 \\
\hline VI & $-85 R-2,115-119$ & PO-2-OL & 39.19 & 60.90 & 0.23 & - & 0.16 & 100.48 \\
\hline
\end{tabular}

$\mathrm{PO}=$ pyrrhotite $; \mathrm{PN}=$ pentlandite $; \mathrm{TR}=$ troilite $; \mathrm{PY}=$ pyrite $; \mathrm{ML}=$ millerite $;=$ primary $; 2=$ secondary; $\mathrm{I}=$ interstitial; $\mathrm{PL}=$ inclusion in plagioclase; $\mathrm{OL}=$ inclusion in olivine; $\mathrm{AMPH}=$ inclusion in amphibole; dash $=$ none detected.

Secondary sulfides occur in trace amounts in recrystallized areas of green amphibole, which also contains disseminated secondary magnetite. Pyrrhotite is most common, chalcopyrite and pyrite are less abundant, and pentlandite is rare. These occur as small (up to a few tens of micrometers) individual grains or intergrowths. Millerite $(\mathrm{NiS})$ was identified in one sample (118-735B-34R-2, 96-100 cm), where it occurs with pentlandite in a $20 \mu \mathrm{m}$ grain in green amphibole. Chalcopyrite, pyrite, and pyrrhotite are present as similar small grains in interstitial areas with chlorite, and in aggregates of granular secondary plagioclase.

Secondary pyrite is scattered in trace amounts throughout the core. It is present in interstitial areas with chlorite, as pseudomorphs of igneous and secondary pyrrhotite, and with smectite in veins and replacing olivine. In Sample 118-735B-58R-4, 54-58 $\mathrm{cm}$, pyrite is common as small $(2-10 \mu \mathrm{m})$ grains disseminated in smectite that replaces plagioclase and in smectite veinlets. Pyrite is most common in the oxide gabbros of Unit IV (and in Sample 118-735B-43R-2, 86-90 cm), where it is the dominant sulfide phase and occurs mainly as pseudomorphs of igneous pyrrhotite (Fig. 4B). The pyrite is generally porous and often intergrown with marcasite in finely crystalline aggregates. Pyrite also pseudomorphs laths of secondary pyrrhotite intergrown with silicates replacing olivine. Little or no pyrrhotite remains in most of these Unit IV samples. The pyrite \pm marcasite pseudomorphs generally are associated with Fe-oxyhydroxides and orange smectite in small veinlets and interstitial areas. Pyrite veinlets, from a few micrometers up to about $40 \mu \mathrm{m}$ in width, cut igneous minerals, talc, green amphibole, and chlorite in two samples from Unit IV (118-735B-52R-2, 22-26 cm, and -53R-2, 53-56 $\mathrm{cm})$. Like the pyrite pseudomorphs, these veinlets are associated with orange smectite. The porous nature of the pyrite pseudomorphs and the association with Fe-oxyhydroxides suggest origin of the pyrite by oxidation of pyrrhotite, with consequent
Fe-loss and volume reduction, rather than sulfidation of pyrrhotite, which would cause a volume increase.

No consistent differences in composition were detected between igneous and secondary pyrrhotites (Table 1). Secondary pentlandites generally have $\mathrm{Ni}$ contents similar to those of igneous pentlandites; however, the secondary pentlandite associated with millerite is Ni-rich $\left(\mathrm{Fe}_{3.0} \mathrm{Ni}_{5.8} \mathrm{~S}_{8}\right)$. Co contents of secondary pentlandites in olivine coronas range to higher values $(5.4 \%-10.1 \%)$ than igneous pentlandites. Like the igneous sulfides, all analyzed secondary $\mathrm{Cu}-\mathrm{Fe}$ sulfides have stoichiometric chalcopyrite compositions.

\section{Sulfur and Carbon Contents}

Sulfur contents of rocks from Hole 735B vary considerably, ranging from 60 to $2530 \mathrm{ppm}$ (Table 2). The extensively recrystallized foliated metagabbros of Unit I have low sulfur contents, averaging only $90 \mathrm{ppm}$ (Fig. 2). In contrast, Unit IV oxide gabbros have high sulfur contents, ranging from 1090 to $2530 \mathrm{ppm}$. These high sulfur contents reflect the abundant igneous sulfides (and pyrite pseudomorphs) observed in the rocks, suggesting that sulfur was concentrated through igneous processes. Units III, V, and VI, which contain the least altered rocks in the core, average 460,510 , and $730 \mathrm{ppm} \mathrm{S}$, respectively, whereas Unit II contains only $300 \mathrm{ppm} \mathrm{S.}$

With the exception of one sample, the carbon contents of Hole $735 \mathrm{~B}$ samples are uniform and range from 150 to $400 \mathrm{ppm}$ (Table 2), and have a mean of $250 \pm 60 \mathrm{ppm}$. This value is identical to that assumed by Staudigel et al. (1989) for the carbon content of the lower oceanic crust. Sample 118-735B$24 \mathrm{R}-2,132-136 \mathrm{~cm}$, contains $1400 \mathrm{ppm} \mathrm{C}$, which is significantly greater than all other samples. The high carbon content of this sample can be attributed to the abundant secondary calcite observed that replaces olivine. 

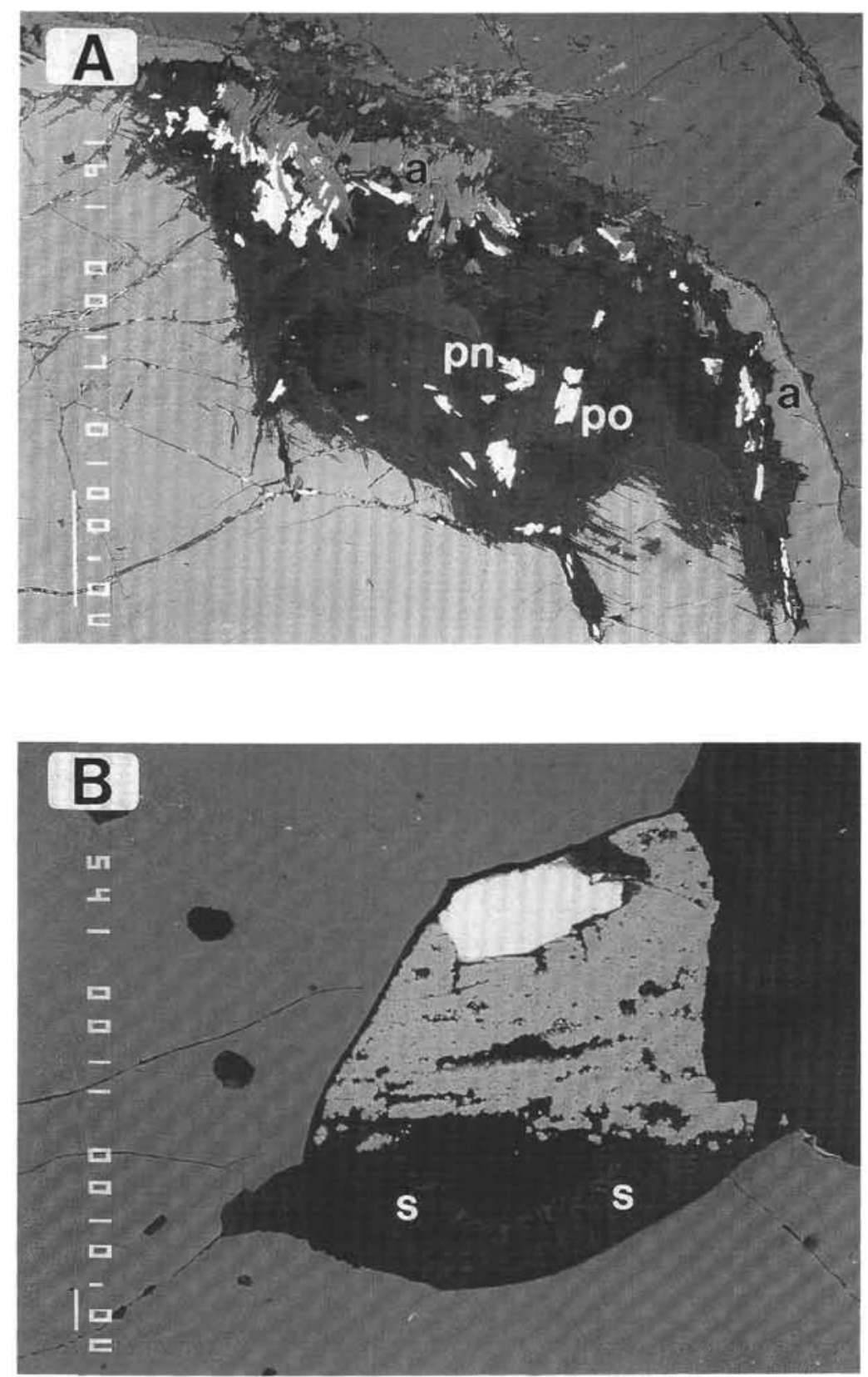

Figure 4. Backscattered electron photomicrographs of secondary sulfides in Hole 735B samples. A. Coronitic alteration of olivine. Olivine (lower left) is replaced by talc (dark gray) and amphibole (lighter gray = a) intergrown with pyrrhotite (po), pentlandite (pn), and magnetite (white). Adjacent grain at upper right is clinopyroxene. Microcracks in olivine are filled with talc and magnetite (white). Scale $=100 \mu \mathrm{m}$. B. Altered igneous sulfide partly enclosed within ilmenite (dark gray) in oxide gabbro from Unit IV. Porous pyrite (light gray) is pseudomorphic after igneous pyrrhotite and is associated with Fe-smectite (S) and relict igneous chalcopyrite (white). Scale bar $=10 \mu \mathrm{m}$.

\section{Sulfur Isotopes}

Results of sulfur isotopic analyses are given in Table 2. The total sulfur extracted for isotopic analyses averages $93 \%$ of the total sulfur content of the rocks, as determined by the LECO combustion technique. The proportions of the different types of sulfur extracted from the rocks vary widely, but monosul- fide, pyrite, and soluble sulfate sulfur average $53 \%, 41 \%$, and $6 \%$, respectively, of the total sulfur.

There do not appear to be any consistent trends in $\delta^{34} \mathrm{~S}$ values with depth or according to lithostratigraphic unit (Fig. 2 ). Monosulfide sulfur has $\delta^{34} S$ values that range from -3.2 to $+6.9 \%$, with a mean of $+0.5 \pm 2.4 \%$. This mean is similar to the average $\delta^{43} \mathrm{~S}$ of sulfur in mid-ocean ridge basalt (MORB) 
Table 2. Sulfur data for Hole 735B.

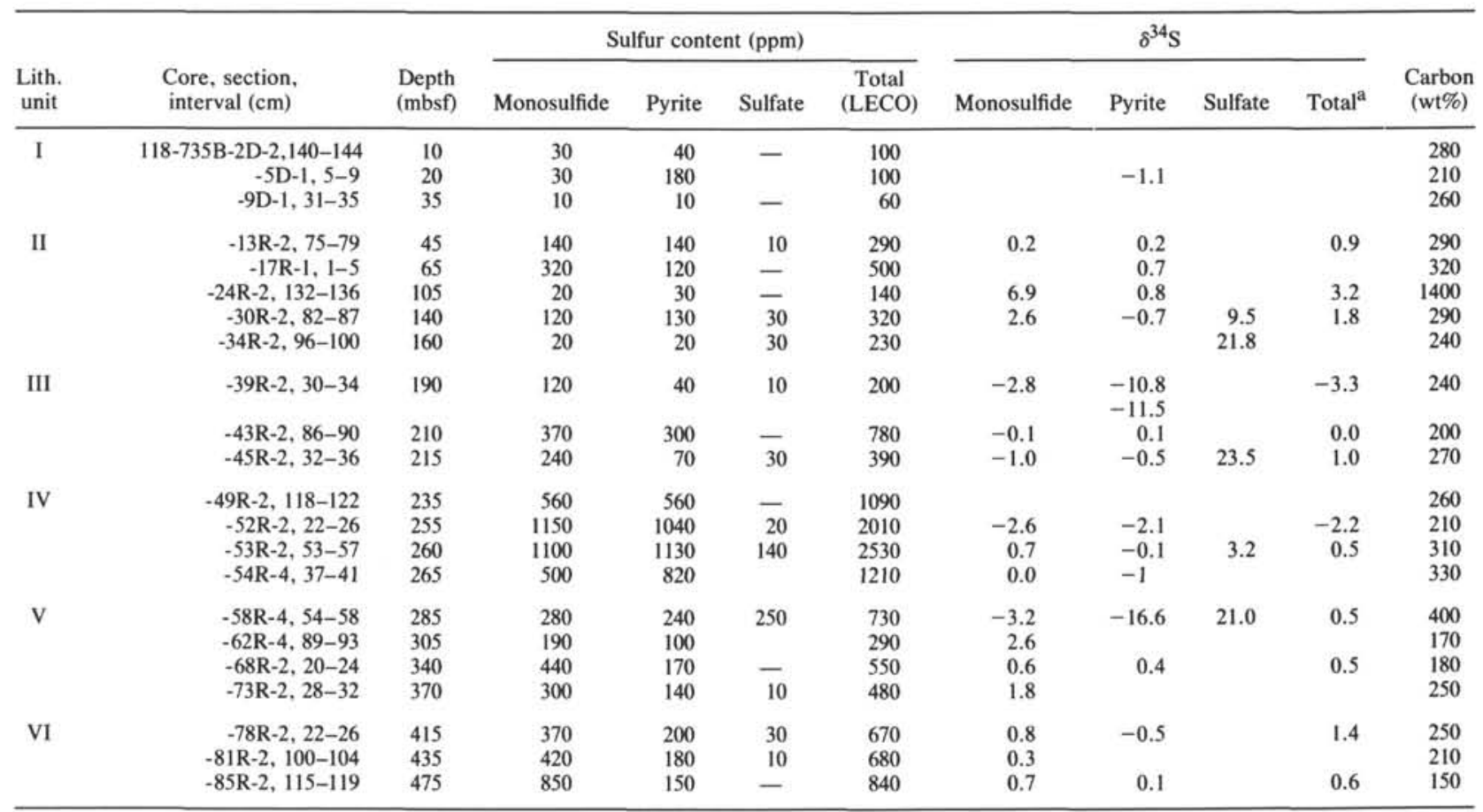

${ }^{a}$ Where $\delta^{34} \mathrm{~S}$ sulfate not analyzed, $\delta^{34} \mathrm{~S}$ total $\mathrm{S}$ calculated assuming $\delta^{34} \mathrm{~S}$ sulfate $=+21 \%$.

Blanks = not analyzed; $\delta^{34} \mathrm{~S}$ in per mil CDT; dashes $=$ none detected.

glasses $(+0.1 \pm 0.5 \%$, Sakai et al., 1984). Nonetheless, significant variations do occur in the isotopic composition of sulfide in Hole 735B (Fig. 2). Two samples (118-735B-39R-2, $30-34 \mathrm{~cm}$, and $-58 \mathrm{R}-4,54-58 \mathrm{~cm}$ ) have highly negative $\delta^{34} \mathrm{~S}$ values for pyrite sulfur ( -11.2 and $-16.6 \%$, respectively). Pyrite sulfur in the other samples has $\delta^{34} \mathrm{~S}$ values that range from -2.1 to $+0.8 \%$, with a mean of $-0.3 \pm 0.8 \%$, near the MORB value. For the pairs analyzed, pyrite sulfur tends to have a lower $\delta^{34} \mathrm{~S}$ value than co-existing monosulfide sulfur (Fig. 2), the reverse of equilibrium fractionation (Ohmoto and Rye, 1979).

The $\delta^{34} \mathrm{~S}$ of soluble sulfate varies widely, from +3.2 to $+23.5 \%$ (Table 2). Three samples have $\delta^{34} \mathrm{~S}$ values near that of seawater $(+21 \%$, Rees et al., 1978; Table 2$)$. The lower $\delta^{34} \mathrm{~S}$ values of sulfate from the other two analyzed samples fall between the values for seawater sulfate and basaltic sulfur (Table 2).

\section{DISCUSSION}

\section{Distribution of Igneous Sulfides and Sulfur}

The assemblages of pyrrhotite \pm pentlandite \pm chalcopyrite \pm troilite in the globular interstitial sulfides and enclosed in cumulate silicate minerals are typical of igneous sulfides separated and crystallized from mafic magmas, and which have re-equilibrated at lower temperatures (Craig and Kullerud, 1969). Troilite is a relatively uncommon igneous sulfide phase that indicates exsolution from $\mathrm{Fe}$-rich pyrrhotite $(>48$ atomic $\% \mathrm{Fe})$ at low temperatures $\left(<140^{\circ} \mathrm{C}\right.$, Kissin and Scott, 1982). The presence of such Fe-rich pyrrhotite indicates lower sulfur fugacities in the troilite + hexagonal pyrrhotitebearing rocks than in those containing only pyrrhotite that is poorer in Fe (Toulmin and Barton, 1964). The troilite-pyrrhotite exsolutions may also indicate lower oxygen fugacity in host rocks than in rocks containing pyrrhotite only (Pasteris, 1984; 1985).
Various processes can account for the distribution of igneous sulfides in Hole $735 \mathrm{~B}$, including accumulation of droplets of immiscible sulfide liquid along with cumulate silicates, as well as separation and crystallization of sulfides from late-stage silicate melt. The common occurrence of sulfides as inclusions in silicates indicates that the melts were saturated with sulfur, causing separation of an immiscible sulfide liquid during at least one period early in the crystallization history. Sulfide might have increased in the gabbroic cumulates of Hole 735B through accumulation of silicates containing these inclusions. Accumulation of immiscible sulfide droplets along with the silicate cumulate phases may also have taken place and is consistent with the occurrence of globular igneous sulfides in interstitial areas. Separation and crystallization of sulfide from crystallizing intercumulus silicate melt can also account for globular interstitial sulfides. In particular, the sulfide and magnetiteplus-ilmenite globules, which are enclosed in brown igneous amphibole rims on pyroxenes, probably formed by this process.

Transition metal contents of whole-rock samples from Hole $735 \mathrm{~B}$ provide additional constraints on what processes may account for the distribution of igneous sulfides in the rocks. Two trends can be observed on plots of $\mathrm{Ni}$ and $\mathrm{Cu}$ vs. $\mathrm{Fe}_{2} \mathrm{O}_{3}{ }^{\mathrm{T}}$ (Fig. 5). First, $\mathrm{Ni}$ and $\mathrm{Cu}$ both increase independently of $\mathrm{Fe}$ at low values of $\mathrm{Fe}_{2} \mathrm{O}_{3} \mathrm{~T}$ in Units $\mathrm{V}$ and $\mathrm{VI}$. $\mathrm{Ni}$ and $\mathrm{Cu}$ are strongly fractionated into sulfide melt relative to coexisting mafic silicate melt (Naldrett, 1981), suggesting that accumulation of immiscible sulfide melt may account for the increases in $\mathrm{Ni}$ and $\mathrm{Cu}$ at low iron contents. There is a slight correlation of $\mathrm{Ni}$ with $\mathrm{Cu}$ in Unit $\mathrm{V}$ (Fig. 6), which may reflect accumulation of sulfides. Samples from Unit VI, as well as from all other units, do not exhibit this correlation, however, suggesting that simple accumulation of sulfide minerals cannot account for the trends of increasing $\mathrm{Cu}$ and $\mathrm{Ni}$ at constant $\mathrm{Fe}$ in Figure 5. These trends are better explained by accumulation 


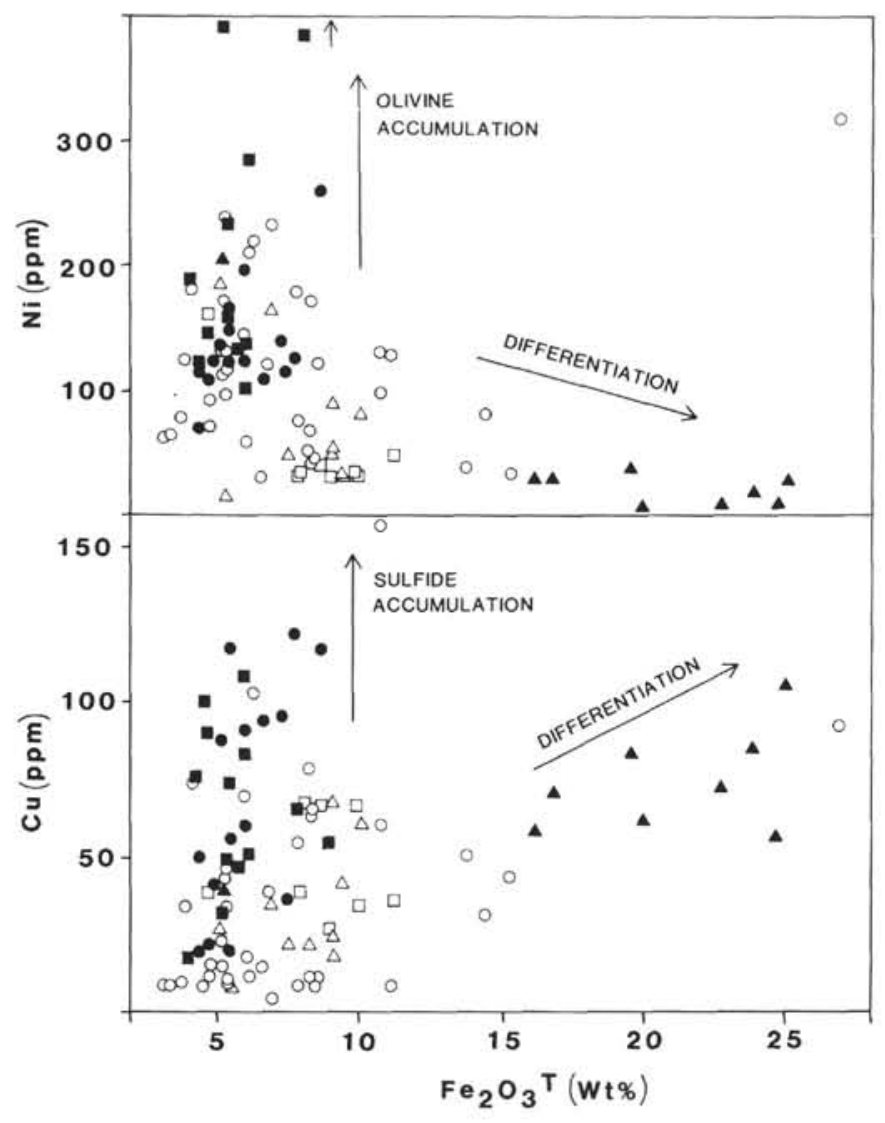

Figure 5. Metal contents of Hole 735B samples vs. $\mathrm{Fe}_{2} \mathrm{O}_{3}{ }^{\mathrm{T}}$. Large arrows indicate approximate trends for olivine and sulfide accumulation and differentiation (see text). Small arrow indicates sample that plots off scale. Open triangles = Unit I; open circles = Unit II; open squares = Unit III; solid triangles = Unit IV; solid circles = Unit V; solid squares $=$ Unit VI. Data from Shipboard Scientific Party (1989).

of both olivine and sulfide. Between olivine and coexisting sulfide melt, $\mathrm{Ni}$ is preferentially partitioned into olivine, whereas $\mathrm{Cu}$ is partitioned into sulfide (Naldrett, 1981; Fleet and MacRae, 1987). Thus, accumulation of olivine can account for the trend of increasing $\mathrm{Ni}$ at constant low $\mathrm{Fe}$, while accumulation of $\mathrm{Cu}$-bearing sulfides can account for the increase of $\mathrm{Cu}$ at constant low $\mathrm{Fe}$ in Units $\mathrm{V}$ and VI.

The second trend of increasing $\mathrm{Cu}$ and decreasing $\mathrm{Ni}$ with rising $\mathrm{Fe}$ contents (Fig. 5) occurs mainly in the oxide gabbros of Unit IV. The high $\mathrm{Fe}$ and $\mathrm{Ti}$ contents of these rocks, the uniformly high $\mathrm{Fe}$ contents of olivine and pyroxene, and the presence of sodic plagioclase all indicate formation from highly differentiated, Fe-rich liquids (Dick et al., this volume). The oxide gabbros are interpreted to have formed through expulsion of highly differentiated Fe-rich intercumulate liquids from crystallizing olivine gabbros into zones of brittleductile deformation, where the liquids penetrated and perhaps reacted with the host olivine gabbros (Dick et al., this volume). The high sulfur contents of the oxide gabbros (Fig. 2) and the abundance of sulfides, as well as Fe-Ti oxides, are consistent with formation from an evolved silicate melt. Factors affecting the sulfur content of basaltic melts include temperature, pressure, $\mathrm{f}_{\mathrm{O}_{2}}$, and melt composition, with the solubility of sulfur increasing significantly as iron content increases (Haughton et al., 1974; Katsura and Nagashima, 1974; Carroll and Rutherford, 1985). The oxide gabbros of

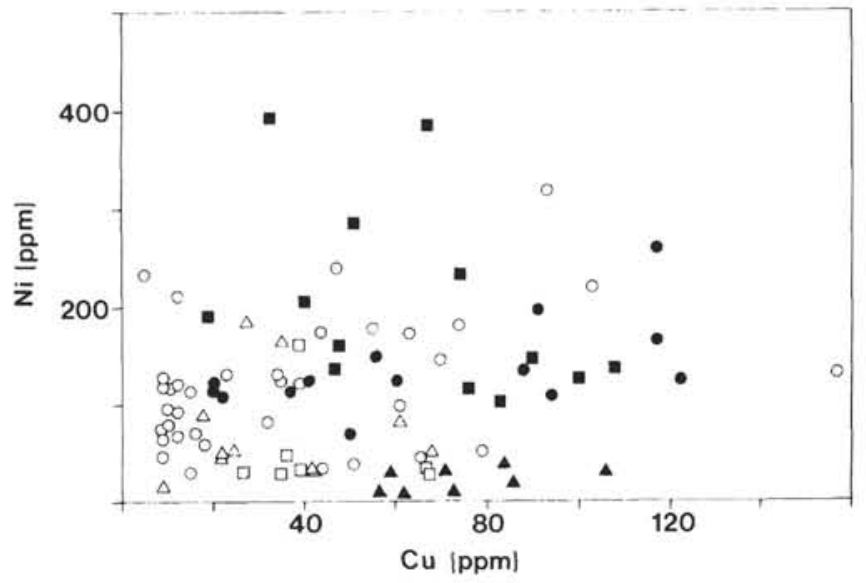

Figure 6. Ni vs. Cu contents for Hole 735B samples. Open triangles $=$ Unit I; open circles = Unit II: open squares = Unit III; solid triangles = Unit IV; solid circles = Unit V; solid squares = Unit VI. Data from Shipboard Scientific Party (1989).

Unit IV have high $\mathrm{Fe}_{2} \mathrm{O}_{3}{ }^{\mathrm{T}}$ contents, ranging up to about 25 wt\% (Shipboard Scientific Party, 1989). The high sulfur contents of these rocks are consistent with differentiation and iron enrichment, with a corresponding increase in the solubility of sulfur in the melts.

The trend of increasing $\mathrm{Cu}$ and $\mathrm{Fe}$ contents of the oxide gabbros in Figure 5 correlates with extremely high sulfur contents (Fig. 2, Table 2). The increase in $\mathrm{Cu}$ in these rocks is attributed to the increase in solubility of $\mathrm{Cu}-\mathrm{Fe}$ sulfide in basaltic melt as Fe content increases (Haughton et al., 1974). Fractional crystallization of olivine and extraction of $\mathrm{Ni}$ from the melt can account for the low Ni contents of these Fe-rich rocks. Separation of immiscible sulfide liquid also occurred, however, which probably contributed to the Ni depletion of these rocks and to the relative $\mathrm{Cu}$-enrichment of the sulfide present.

Segregation of sulfide liquid from a basaltic melt generally begins with separation of a $\mathrm{Ni}-\mathrm{Fe}-\mathrm{Cu}$ sulfide liquid, with the $\mathrm{Ni} /\left(\mathrm{Ni}^{+} \mathrm{Cu}\right)$ ratio of subsequent sulfide decreasing as separation of sulfide proceeds (Duke, 1979; , Naldrett, 1981). Mafic intrusions typically exhibit this effect in the sequence from early pyrrhotite + pentlandite + chalcopyrite assemblages to later pyrrhotite + chalcopyrite assemblages (Chamberlain, 1967; Naldrett, 1981). The distribution of igneous sulfides in rocks from Hole $735 \mathrm{~B}$ is consistent with these trends. Igneous sulfides in Units II, III, V, and VI from Hole 735B are characterized by pyrrhotite + pentlandite + chalcopyrite $( \pm$ troilite) assemblages, whereas igneous sulfides in Unit IV oxide gabbros lack pentlandite and are composed of chalcopyrite + pyrrhotite (the pyrrhotite is now mostly pseudomorphed by secondary pyrite and marcasite). The lowest $\mathrm{Ni}$ contents of pyrrhotite also occur in Unit IV, consistent with prior extraction of $\mathrm{Ni}$ in olivine and sulfide. Fractionation of olivine plus sulfide from mafic magmas results in a progressive decrease in the $\mathrm{Ni} / \mathrm{Co}$ ratio of sulfide separating from the melt (Duke, 1979; Naldrett, 1981). This process thus might also account for the relatively high Co contents of pyrrhotite in the oxide gabbros of Unit IV.

\section{Secondary Sulfides and Behavior of Sulfur During Hydrothermal Alteration}

The sulfide mineralogy and behavior of sulfur resulting from the alteration of Hole $735 \mathrm{~B}$ gabbros are discussed in 
relation to the major metamorphic processes that affected silicate minerals in the rocks (dynamothermal metamorphism, brittle deformation and static metamorphism, and low temperature alteration). To understand the behavior of sulfur during hydrothermal alteration, however, some constraints must be placed on the original, igneous sulfur contents of the rocks. Various information indicates that the most altered rocks occur in the upper $200 \mathrm{~m}$ of the core: extensively recrystallized foliated metagabbros occur in Unit I; amphibole + plagioclase veins are most abundant in the upper $200 \mathrm{~m}$ of the core, reaching maximum abundance in Units II and III (Vanko and Stakes, this volume); secondary amphibole in the rock matrix is most abundant in the upper $150 \mathrm{~m}$ of the core (Dick et al., this volume); and pyroxenes have elevated ${ }^{87} \mathrm{Sr} /{ }^{86} \mathrm{Sr}$ ratios in the upper $200 \mathrm{~m}$, indicating greater extent of interaction with seawater in the upper half of the core (Kempton and Hawkesworth, 1988). Thus, excluding the unusual oxide gabbros of Unit IV, the least altered rocks occur in Units V and VI. Petrographically, these rocks are mostly unaltered. Sulfides contained in the rocks are predominantly igneous, with only traces of secondary sulfides present in alteration rims on olivine. Sulfur contents of samples from Units V and VI range from 430 to $790 \mathrm{ppm}$, with a mean of $610 \pm 180 \mathrm{ppm}$. This value is taken as the starting igneous sulfur content of gabbroic rocks from Hole $735 \mathrm{~B}$. Because Hole $735 \mathrm{~B}$ rocks are cumulates, however, this sulfur content does not represent the sulfur content of the parental magmas.

The foliated metagabbros of Unit I are depleted in sulfur relative to the rest of the core (Fig. 2). This sulfur depletion correlates with the near absence of igneous sulfides from the rocks, and with the presence of only traces of secondary sulfide minerals, implying that early dynamothermal metamorphism resulted in breakdown of igneous sulfides and nearly complete loss of sulfur from the rocks. Additional sulfur may have been lost from the rocks during subsequent veining and static metamorphism and late, low-temperature alteration (see below), but these processes also affected the upper $200 \mathrm{~m}$ of the core, whereas there is a distinct break in sulfur contents at the base of Unit 1 (Fig. 2). This suggests that the main process responsible for the sulfur depletion of Unit I was early plastic deformation and high temperature metamorphism $\left(600^{\circ}-\right.$ $700^{\circ} \mathrm{C}$; Vanko and Stakes, this volume).

Subsequent brittle deformation and associated static hydrothermal metamorphism also resulted in loss of sulfur from the more extensively altered rocks. Igneous sulfides are scarce or absent in extensively altered portions of the rocks containing abundant green amphibole and secondary plagioclase associated with hornblende veins (e.g., in Unit II). These zones also contain only traces of secondary sulfide minerals. Unit II, which was significantly affected by alteration of this type, contains on average $300( \pm 130) \mathrm{ppm} \mathrm{S}$, significantly less than the least altered rocks from the core $(600 \mathrm{ppm})$, indicating that sulfur was lost from the rocks to hydrothermal fluids during brittle deformation and static metamorphism.

Even though sulfur was locally lost from the rocks at this stage, secondary sulfides formed in trace amounts throughout the core during static metamorphism. These include the sulfides enclosed in green amphibole, but the most common secondary sulfides are associated with altered olivine. Most secondary sulfides probably formed by recrystallization of igneous sulfide, but sulfur isotopic data indicate at least local incorporation of a component of sulfide derived from reduced seawater sulfate (see section on sulfur isotopes). Temperatures estimated for the reaction of olivine to anthophyllite + magnetite or talc + magnetite at $\mathrm{P}_{\mathrm{H}_{2} \mathrm{O}}=\mathrm{P}_{\text {total }}=0.5$ to $2 \mathrm{kbar}$ are in the range of $500^{\circ}-600^{\circ} \mathrm{C}$ (Ferry, 1985 ; Bird et al., 1988). These temperature estimates are similar to those for most of the hornblende-plagioclase veins in Hole 735B core (Vanko and Stakes, this volume). The presence of talc + magnetite and $\mathrm{Mg}-\mathrm{Fe}$ amphibole + magnetite along microcracks in olivine in relatively fresh rocks suggests that these minerals formed at very low water/rock ratios. Oxidation of $\mathrm{Fe}^{2}+$ in olivine probably occurred through the decomposition of water during initial hydration reactions such as:

$$
\begin{aligned}
& 1.104 \mathrm{H}_{2} \mathrm{O}+1.67\left(\mathrm{Fe}_{0.2} \mathrm{Mg}_{1.8}\right) \mathrm{SiO}_{4}+2.33 \mathrm{SiO}_{2}(\mathrm{aq})= \\
& 0.111 \mathrm{Fe}_{3} \mathrm{O}_{4}+\mathrm{Mg}_{3} \mathrm{Si}_{4} \mathrm{O}_{10}(\mathrm{OH})_{2}+0.104 \mathrm{H}_{2} \text {. } \\
& \text { magnetite talc }
\end{aligned}
$$

The last secondary minerals to form in the rocks were low-temperature phases: smectite \pm sulfides (pyrrhotite, pyrite) \pm carbonate $\pm \mathrm{Fe}$ oxyhydroxides in veinlets and reptacing olivine. This low-temperature alteration probably occurred through circulation of cold seawater along permeable zones and may be related to fracturing associated with uplift of the gabbroic block. Conditions varied from more reducing (smectite \pm pyrrhotite \pm pyrite \pm carbonate) to more oxidizing (smectite $+\mathrm{Fe}$ oxyhydroxides \pm carbonate). This stage resulted in formation of secondary sulfides in some rocks, whereas small amounts of sulfur were probably lost from others through oxidation of sulfides. Fe-oxyhydroxides are scattered in trace amounts throughout the core; thus, there does not appear to be a distinct zone of "seafloor weathering" and consequent sulfur loss, such as occurs in the volcanic section of ocean crust (Alt et al., 1989). The replacement of igneous and secondary pyrrhotite by pyrite and marcasite most likely occurred during late, low-temperature alteration. By analogy with the formation of similar phases in submarine basalts, low-temperature alteration probably occurred at temperatures less than $100^{\circ} \mathrm{C}$, perhaps approaching $0^{\circ} \mathrm{C}$ (Bohlke et al., 1984). Sulfide phases in rocks from Hole 735B (troilite, millerite) indicate at least partial re-equilibration at low temperatures (less than about $100^{\circ} \mathrm{C}$; Craig, 1973; Kissin and Scott, 1982); however, we are uncertain how cooling of the rocks and re-equilibration of sulfides at these temperatures relate to the timing of low-temperature alteration.

\section{Sulfur Isotopes}

Most of the sulfide $\delta^{34} \mathrm{~S}$ values for Hole 735B are near that for sulfur in MORB glasses $(+0.1 \pm 0.5 \%$, Sakai et al., 1984), reflecting primary magmatic sulfur from a MORB-type mantle source (Fig. 7). Sulfide from the least altered rocks in Units V and VI (excluding Sample 118-735B-58R-4, 54-58 cm, discussed below) has $\delta^{34} \mathrm{~S}$ values that average $+0.8 \pm 0.9 \%$, and most of the sulfide from Hole $735 \mathrm{~B}$ is within $\pm 2 \%$ of the MORB value (Fig. 7), which can be attributed to primary igneous processes. Mafic intrusions exhibit similar variation in the isotopic composition of sulfide, with $\delta^{34} \mathrm{~S}$ mostly ranging from -1.5 to around $+5 \%$ (Fig. 7; Thode et al., 1962; Shima et al., 1963; Sasaki, 1969a, 1969b). In some cases, $\delta^{34} \mathrm{~S}$ of sulfide increases with differentiation in mafic intrusions, whereas in others no clear trend is evident, or $\delta^{34} \mathrm{~S}$ may decrease in more differentiated rocks (Thode et al., 1962; Shima et al., 1963; Sasaki, 1969a, 1969b). Slight variations in oxygen and sulfur fugacities implied by the presence or absence of igneous troilite in Hole $735 \mathrm{~B}$ rocks could affect the speciation of sulfur in the melt (Katsura and Nagashima, 1974; Ueda and Sakai, 1984), consequently resulting in slight vari- 


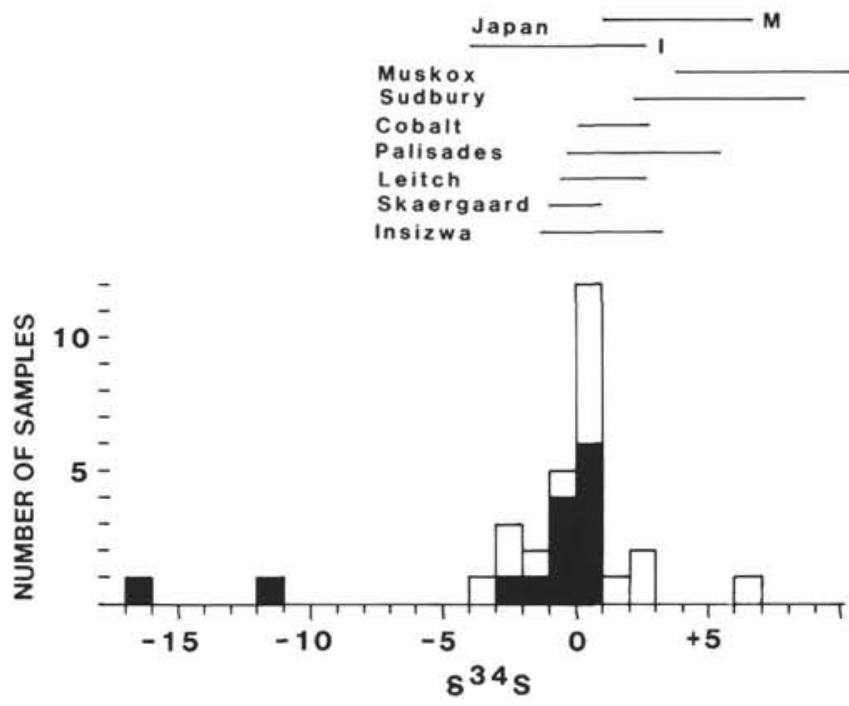

Figure 7. Histogram of sulfide $\delta^{34} \mathrm{~S}$ values from Hole 735B. Open symbols $=$ monosulfide sulfur; solid symbols $=$ pyrite sulfur. Ranges of $\delta^{34} \mathrm{~S}$ for sulfide in gabbroic intrusions shown for comparison (Data from Thode et al., 1962; Shima et al., 1963; Sasaki, 1969a, 1969b; Sasaki and Ishihara, 1977). For Japan data, I = ilmenite series; M = magnetite series.

ations in $\delta^{34} \mathrm{~S}$ of sulfides. Depending upon the speciation of sulfur in the magma (the proportion of sulfide vs. sulfate sulfur), separation and removal of sulfide minerals from the silicate melt could result in small increases or decreases of a few per mil in $\delta^{34} \mathrm{~S}$ of residual sulfide in the magma (Ueda and Sakai, 1984).

Monosulfide sulfur in Sample 118-735B-24R-2, 132-136 cm, $(+6.9 \%$, Table 2$)$ has a significantly higher $\delta^{34} \mathrm{~S}$ value than that in the other samples. Mafic intrusions exhibit similar spreads in $\delta^{34} \mathrm{~S}$ values of 2 to $7 \%$ (Fig. 7), so that the high $\delta^{34} \mathrm{~S}$ value from Hole $735 \mathrm{~B}$ might conceivably be attributed to igneous variation. Sample 118-735B-24R-2, 132-136 cm, however, is extensively recrystallized, has a very low sulfur content, and the only sulfides observed in thin section are secondary (pyrrhotite and chalcopyrite in olivine coronas and in green amphibole). These observations suggest that monosulfide minerals in the rock formed from hydrothermal fluids containing a mixture of sulfide derived from basaltic (near $0 \%$ ) and seawater $(+21 \%$, Rees et al., 1978) sources. (The relatively low $\delta^{34} \mathrm{~S}$ value of coexisting pyrite in this sample [Table 2] is due to late, low-temperature formation of pyrite [see below].)

Extensively altered basalts from DSDP Hole 504B are similarly enriched in ${ }^{34} \mathrm{~S}$, although these are interpreted to have formed where upwelling hydrothermal fluids mixed with seawater in the shallow subsurface (Alt et al., 1989). Reduction of seawater sulfate and incorporation into sulfide minerals are interpreted to have occurred in proximity to the shallow mixing zone in Hole 504B, whereas sulfide in upwelling hydrothermal fluids originating at depth in the crust is believed to be rock-dominated, with $\delta^{34} \mathrm{~S}$ values around $+1 \%$ (Shanks and Seyfried, 1987; Alt et al., 1989; Bowers, 1989). Modeling of sulfur in submarine hydrothermal systems, however, predicts a zone where both reduction of seawater sulfate and the $\delta^{34} \mathrm{~S}$ of sulfide in hydrothermal fluids reach maxima at depth in the crust (Bowers, 1989). These fluids then react and equilibrate in the rock-dominated system, and the sulfide acquires a $\delta^{34} \mathrm{~S}$ value approaching that of the unaltered rock. The high $\delta^{34} \mathrm{~S}$ value of monosulfide sulfur in Sample 118-735B-24R-2, $132-136 \mathrm{~cm}$, may have derived from fluids containing a mixture of basaltic sulfide and sulfide from reduction of seawater sulfate, which penetrated relatively deep into the crust. Sample 118B-735B $30 \mathrm{R}-2,82-87 \mathrm{~cm}$, is similar to -Sample 118B-735B-24R-2, 132-136 cm: it is extensively recrystallized and only secondary sulfides are observed in thin section. This sample also has a relatively high $\delta^{34} \mathrm{~S}$ value for monosulfide sulfur $(+2.6 \%)$, which may similarly be due to incorporation of seawater-derived sulfide. In contrast, Sample 118-735B-13R-2, 75-79 cm, which is from the same lithologic unit as the above samples, contains monosulfide sulfur with $\delta^{34} \mathrm{~S}$ of $+0.2 \%$. This is near the presumed igneous value (around $+0.1 \%$ ), suggesting incorporation of little or no seawater-derived sulfide. Indeed, this sample is only slightly recrystallized and retains igneous sulfides, consistent with incorporation of little or no seawater-derived sulfur.

Pyrite sulfur commonly has $\delta^{34} \mathrm{~S}$ values that are lower than coexisting monosulfide sulfur in Hole 735B (Fig. 2). This fractionation is in the opposite sense for equilibrium, where pyrite is enriched in ${ }^{34} \mathrm{~S}$ relative to coexisting monosulfide minerals (Ohmoto and Rye, 1979). The low $\delta^{34} \mathrm{~S}$ values of pyrite relative to monosulfide sulfur can be accounted for by the presence of a component of late, low-temperature pyrite, which has lower $\delta^{34} \mathrm{~S}$ values. In particular, pyrite sulfur from Sample 118-735B-58R-4, 54-58 cm, has the lowest measured $\delta^{34} \mathrm{~S}$ value from Hole $735 \mathrm{~B}(-16.6 \%$, Table 2$)$. This sample is unique in that it is part of a hydrothermal breccia containing a vein of clinopyroxene, zoisite, actinolite, chlorite, sphene, and plagioclase, as well as abundant late, low-temperature smectite. Small grains of disseminated secondary pyrite are common in the smectite in veinlets and replacing plagioclase in this sample. Pyrite associated with similar low temperature alteration of submarine basalts has comparable low $\delta^{34} \mathrm{~S}$ values, mostly ranging from -24 to $+2 \%$ (Krouse et al., 1977; Hubberten, 1983; Belyi et al. 1983. Field et al 1984) The most likely explanation for such low $\delta^{34} \mathrm{~S}$ values involves partial oxidation of igneous sulfides by seawater at low temperatures $\left(<100^{\circ} \mathrm{C}\right.$; Andrews, 1979; Belyi et al., 1983). This produces sulfur species of intermediate oxidation state, which are unstable in solution and disproportionate into oxidized sulfate and reduced sulfide components. Fractionation of sulfur isotopes between the oxidized and reduced species (Uyama et al., 1985) leads to loss of ${ }^{34} \mathrm{~S}$-rich sulfate to seawater, whereas ${ }^{34} \mathrm{~S}$-depleted sulfide can form secondary pyrite with low $\delta^{34} \mathrm{~S}$ values. Significant amounts of secondary pyrite were not observed in the thin section of the other sample with a low $\delta^{34} \mathrm{~S}$ value for pyrite sulfur (Sample 118-735B-39R-2, 30-34 $\mathrm{cm},-11 \%$, Table 2 ). Instead, the rock appears mostly fresh with common igneous sulfides present, along with traces of secondary pyrrhotite and chalcopyrite in green amphibole and with talc and $\mathrm{Mg}$-Fe-amphibole replacing olivine. Smectite occurs in this sample replacing olivine and in small veinlets. Although no pyrite was observed, it is possible that lowtemperature pyrite is present in this sample, perhaps in a veinlet, but that it was not intersected by the thin section. This would account for the presence of a small amount of pyrite sulfur with a low $\delta^{34} \mathrm{~S}$ value.

The three samples that have pyrite sulfur with $\delta^{34} \mathrm{~S}$ values less than $-2 \%$ also have low $\delta^{34} \mathrm{~S}$ values for monosulfide sulfur $(<-2 \%$; Fig. 2, Table 2$)$. This suggests that in these samples there may be a component of late, low-temperature monosulfide (pyrrhotite or chalcopyrite) with low $\delta^{34} \mathrm{~S}$ values that formed through processes similar to those giving rise to the late pyrite. Indeed, secondary chalcopyrite with low $\delta^{34} \mathrm{~S}$ values occurs in seafloor basalts altered at low temperatures (Hubberten, 1983).

The isotopic compositions of sulfate extracted from Hole 735B samples are generally consistent with introduction of seawater during late, low-temperature alteration. The $\delta^{34} \mathrm{~S}$ of 
sulfate from two samples $(+21.0$ and $+21.8 \%$, Table 2$)$ are essentially the same as seawater sulfate $(+21 \%$, Rees et al., 1978) and suggest incorporation of seawater sulfate in pore fluids of the rocks. If the large amount of sulfate in Sample 118-735B-58R-4, 54-58 cm, (250 $\mathrm{ppm} \mathrm{SO}_{4}$ sulfur, Table 2) was caused by the presence of seawater in pore spaces, however, this would require a porosity of $30 \%$. Porosities of rocks from Hole $735 \mathrm{~B}$ are generally less than 3\% (Shipboard Scientific Party, 1989), suggesting either that sulfate was somehow concentrated in seawater-derived pore fluids, or more likely, that a sulfate phase (e.g., anhydrite) is present in small amounts. The isotopic compositions of sulfate from other samples, however, indicate interaction of seawater with the rocks.

The relatively low $\delta^{34} \mathrm{~S}$ values of sulfate from two samples $(+3.2,+9.5 \%$, Table 2$)$ are consistent with the process proposed above for the formation of secondary pyrite through partial oxidation of igneous sulfide. The complement to the secondary pyrite that is depleted in ${ }^{34} \mathrm{~S}$ compared to igneous sulfide is sulfate enriched in ${ }^{34} \mathrm{~S}$ relative to basaltic sulfide. For example, Sample 118-735B-53R-2, 53-57 cm, contains sulfate with $\delta^{34} \mathrm{~S}=$ $+3.2 \% \circ$ and pyrite sulfur with $\delta^{34} \mathrm{~S}=-0.1 \%$, but the $\delta^{34} \mathrm{~S}$ of total sulfur in the rock is $+0.5 \%$, similar to sulfur in fresh glassy MORB. A similar argument could be made for Sample 118-735B$58 \mathrm{R}-4,54-58 \mathrm{~cm}$, which contains pyrite and sulfate sulfur having $\delta^{34} \mathrm{~S}$ values of -16.6 and $+21 \%$, respectively, yet the $\delta^{34} \mathrm{~S}$ of total sulfur is $+0.5 \%$, similar to MORB (Table 2). Alternatively, and perhaps more likely, the sulfate $\delta^{34} \mathrm{~S}$ values intermediate between basaltic and seawater values could reflect mixtures of seawater sulfate with sulfate derived from oxidation of basaltic sulfide without isotopic fractionation.

Sulfate from Sample 118-735B-45R-2, 32-36 cm, is slightly enriched in ${ }^{34} \mathrm{~S}$ relative to seawater $(+23.5 \%)$, consistent with derivation from seawater sulfate through partial reduction of sulfate to sulfide. The sulfate would be in isotopic equilibrium with the sulfide in the sample $(-0.5$ to $-1.0 \%)$ at a temperature of about $250^{\circ} \mathrm{C}$ (Ohmoto and Rye, 1979). This temperature is greater than those proposed for the late, low-temperature alteration (less than about $100^{\circ} \mathrm{C}$ ), however, and could reflect earlier alteration at somewhat higher temperatures.

\section{Significance of Results From Hole 735B}

Our results from Hole $735 \mathrm{~B}$ indicate that $\mathrm{S}$ is lost from gabbros during hydrothermal alteration. The least altered rocks from Hole 735B (Units V and VI) contain an average of $610 \mathrm{ppm} \mathrm{S}$. Relative to these rocks, the foliated metagabbros of Unit I have lost significant amounts of sulfur $(85 \%$ of initial sulfur), which is attributed mostly to early dynamothermal metamorphism. The rocks of Unit II, which were affected mainly by brittle deformation and static metamorphism, contain $300 \mathrm{ppm} \mathrm{S}$, having lost approximately one-half their sulfur relative to the least altered rocks. These results suggest that gabbros of layer 3 contribute mantle sulfur to hydrothermal fluids in submarine hydrothermal systems, and may be a source of sulfur for sulfide deposits on and beneath the seafloor.

The mean isotopic composition of total sulfur in Hole 735B is indistinguishable from magmatic sulfide. The average $\delta^{34} \mathrm{~S}$ of total sulfur (sulfide plus sulfate, Table 2 ) is $+0.4 \pm 1.8 \%$. (The rare breccia Sample 118-735B-58R-4, 54-58 cm, which has the very low $\delta^{34} \mathrm{~S}$ for pyrite sulfur, was excluded from the calculation.) The average represents a maximum value, because where sulfate was not isotopically analyzed, we assumed that sulfate has $\delta^{34} \mathrm{~S}$ equal to seawater $(+21 \%$, whereas actual values could be lower (e.g., measured values as low as $+3.2 \%$, Table 2 ).
The mean $\delta^{34} \mathrm{~S}$ of total sulfide sulfur for samples with both monosulfide and pyrite sulfur analyses is $-0.1 \pm 1.6 \%$ and is not significantly different from the average for total sulfur. These average values are indistinguishable from the mean value for sulfur in MORB glasses $(+0.1 \pm 0.5 \%$, Sakai et al., 1984) and indicate no significant net change in the isotopic composition of sulfur in Hole 735B from the presumed MORB mantle value, either as a result of magmatic processes or seawater interaction. Thus, although our results for Hole 735B indicate that layer 3 gabbros contain seawater-derived sulfur locally as soluble sulfate or fixed as sulfide, this ${ }^{34} \mathrm{~S}$-enrichment at Hole 735B appears to be offset by the formation of late, low $-\delta^{34} \mathrm{~S}$ secondary pyrite at low temperatures.

Results from Hole $735 \mathrm{~B}$ thus indicate that the ultimate effects of seawater interaction on sulfur in oceanic layer 3 are (1) loss of crustal sulfur to hydrothermal fluids and (2) little or no net change in isotopic composition of sulfur in layer 3.

\section{SUMMARY AND CONCLUSIONS}

Igneous sulfides in gabbroic rocks from Hole $735 \mathrm{~B}$ comprise pyrrhotite, chalcopyrite, pentlandite, and troilite, and are generally typical of sulfides formed from mafic magmas. The sulfides occur interstitial to cumulate silicates and as inclusions in plagioclase and pyroxene, and formed by accumulation of immiscible sulfide droplets and crystallization from intercumulus liquids. Trends toward high $\mathrm{Cu}$ and $\mathrm{Ni}$ contents at low $\mathrm{Fe}$ contents are consistent with accumulation of sulfide and olivine in Units V and VI. Troilite formed as exsolutions from Fe-rich pyrrhotite $(>48$ atomic $\% \mathrm{Fe})$ as the rocks cooled to temperatures less than $140^{\circ} \mathrm{C}$. Fe-rich pyrrhotite (+troilite) formed in rocks at lower sulfur, and perhaps oxygen, fugacities than those that contain pyrrhotite only. The least altered rocks contain an average of $610 \mathrm{ppm} \mathrm{S}$, and the mean sulfide $\delta^{34} \mathrm{~S}$ value is near $0 \%$, similar to the isotopic composition of sulfur in MORB glasses. Slight variations in $\delta^{34} \mathrm{~S}$ of sulfide may have been caused by variations in sulfur and oxygen fugacities and by fractionation of sulfide from the silicate melts. The oxide gabbros of Unit IV have high $\mathrm{S}$ and $\mathrm{Cu}$ contents (1090-2530 ppm S), very low Ni contents, and lack pentlandite. These effects result from fractionation of olivine and $\mathrm{Ni}$-sulfide and from the increased solubility of $\mathrm{Cu}-\mathrm{Fe}$ sulfides in differentiated $\mathrm{Fe}$-rich melts.

The foliated metagabbros of Unit I, which were affected by early dynamothermal metamorphism, have lost sulfur and average only $90 \mathrm{ppm} \mathrm{S}$. Samples from the upper $200 \mathrm{~m}$ of the core, which underwent subsequent static hydrothermal alteration, also lost sulfur. Unit II (which exhibits these effects) contains an average of $300 \mathrm{ppm} \mathrm{S}$. Some altered rocks from Unit II have elevated $\delta^{34} \mathrm{~S}$ values for monosulfide sulfur (up to $+6.9 \%$, suggesting local formation of sulfides from mixtures of remobilized basaltic sulfur plus sulfide derived from reduction of seawater sulfate. Traces of secondary sulfides (mostly pyrrhotite, with lesser chalcopyrite, pentlandite, troilite, and pyrite) occur throughout the core. Secondary sulfides are most common in the ubiquitous olivine alteration coronas, but also occur interstitially and in recrystallized areas of green amphibole. Pyrite forms small veinlets and locally replaces igneous pyrrhotite, particularly in the oxide gabbros of Unit IV. Replacement of igneous pyrrhotite probably occurred through oxidation during late, low-temperature alteration. Rocks containing abundant secondary pyrite associated with late, low-temperature smectitic alteration have low $\delta^{34} \mathrm{~S}$ values for pyrite sulfur (to $-16.6 \%$ ). These low values are attributed to isotopic fractionation produced during partial oxidation of igneous sulfides by cold seawater. The rocks contain small amounts of soluble sulfate ( $6 \%$ of total S), which 
is composed of variable proportions of seawater sulfate and oxidized basaltic sulfur.

The ultimate effect of secondary processes on layer 3 gabbros is a loss of sulfur to hydrothermal fluids. This sulfur is likely redeposited as sulfide mineralizations within the crust or at the seafloor. Local ${ }^{34} \mathrm{~S}$-enrichments attributed to the fixation of seawater sulfur in hydrothermally altered rocks and to incorporation of seawater sulfate in pore fluids or as traces of anhydrite appear to be offset by the formation of late, low- $\delta^{34} \mathrm{~S}$ secondary pyrite during low-temperature alteration. This results in little or no net effect of secondary processes on the average isotopic composition of total sulfur in the rocks $(+0.4 \pm 1.8 \%$ o).

\section{ACKNOWLEDGMENTS}

This research was supported by NSF OCE- 8608886 . Thanks to Jay Matthews for diligent laboratory work and to Brian Popp for the LECO analyses. The authors benefitted from discussions with and comments by $\mathrm{S}$. Bloomer, P. Herzig, J. Luhr, J. Pasteris, D. Sassani, W. C. Shanks, E. Shock, D. Stakes, D. Vanko, and L. Walter. Sherm Bloomer and Dave Vanko provided preprints of their work on the drill core, which helped put the sulfur scenario in perspective. Comments by two ODP reviewers also helped to improve the manuscript.

\section{REFERENCES}

Alt, J. C., and Anderson, T. F., 1988. The distribution of sulfur in the oceanic crust, DSDP/ODP Holes 504B and 735B. EOS Trans., 69:1402. (abstract)

Alt, J. C., Anderson, T. F., and Bonnell, L., 1989. The geochemistry of sulfur in a $1.3 \mathrm{~km}$ section through the upper oceanic crust, DSDP Hole 504B. Geochim. Cosmochim. Acta, 53:1011-1023.

Andrews, A. J., 1979. On the effect of low-temperature seawaterbasalt interaction on the distribution of sulfur in oceanic crust, layer 2. Earth Planet. Sci. Lett., 6:68-80.

Belyi, V. M., Migdisov, A. A., Barskaya, N. V., and Grinenko, V. A., 1983. Sulfur isotope composition of hydrothermal sulfides from Hole 504B, DSDP Leg 70, Costa Rica Rift. In Bonnorez, J., Von Herzen, R. P., et al., Init. Repts. DSDP, 70: Washington (U.S. Govt. Printing Office), 619-627.

Bird, D. K., Manning, C. E., and Rose, N. M., 1988. Hydrotherma alteration of tertiary layered gabbros, east Greenland. Am. J. Sci. 288:405-457.

Bohlke, J. K., Alt, J. C., and Muehlenbachs, K. M., 1984. Oxygen isotope-water relations in altered deep sea basalts: low-temperature mineralogical controls. Can. J. Earth Sci., 21:67-77.

Bowers, T. S., 1989. Stable isotope signatures of water-rock interaction in mid-ocean ridge hydrothermal systems: sulfur, oxygen, and hydrogen. J. Geophys. Res., 94:5775-5786.

Canfield, D. E., Raiswell, R., Westrich, J. T., Reaves, C. M., and Berner, R. A., 1986. The use of chromium reduction in the analysis of reduced inorganic sulfur in sediments and shales. Chem. Geol., 54:149-155.

Carroll, M. R., and Rutherford, J., 1985. Sulfide and sulfate saturation in hydrous silicate melts. Proc., 15th Lunar Planet. Sci. Conf. 601-612.

Chamberlain, J. A., 1967. Sulfides in the Muskox intrusion. Can. $J$. Earth Sci., 4:105-153.

Chaussidon, M. F., Albarede, F., and Sheppard, S.M.F., 1987. Sulphur isotope heterogeneity in the mantle from ion microprobe measurements of sulphide inclusions in diamonds. Nature, $330: 242-244$

Craig, J. R., 1973. Pyrite-pentlandite assemblages and other low temperature relations in the $\mathrm{Fe}-\mathrm{Ni}-\mathrm{S}$ system. Am. J. Sci., 273(A):496-510.

Craig, J. R., and Kullerud, G., 1969. Phase relations in the Cu-Fe-Ni$\mathrm{S}$ system and their application to magmatic ore deposits. Econ Geol. Monogr., 4:344-358.
Duke, J. M., 1979. Computer simulation of the fractionation of olivine and sulfide from mafic and ultramafic magmas. Can. Mineral., 17:507-514.

Edmond, J. M., Measures, C., McDuff, R. E., Chan, L. H., Collier, R., Grant, B., Gordon, L. 1., and Corliss, J. B., 1979. Ridge crest hydrothermal activity and the balances of the major and minor elements in the ocean: the Galapagos data. Earth Planet. Sci. Lett., 46:1-18.

Ferry, J. M., 1985. Hydrothermal alteration of tertiary igneous rocks from the Isle of Skye, northwest Scotland, 1. Gabbros. Contrib. Mineral. Petrol., 91:264-282.

Field, C.W., Sakai, H. and Ueda, A., 1984. Isotopic constraints on the origin of sulfur in oceanic rocks. In Wauschkuhn, A., Kluth, C., and Zimmermann, R. A. (Eds.), Syngenesis and Epigenesis in the Formation of Mineral Deposits: Berlin-Heidelberg-New YorkTokyo (Springer-Verlag), 573-589.

Fleet, M. E., and MacRae, N. D., 1987. Partition of Ni between olivine and sulfide: the effect of temperature, $\mathrm{f}_{\mathrm{O} 2}$ and $\mathrm{f}_{/ \mathrm{S} 2}$. Contrib. Mineral. Petrol., 95:336-342.

Harmon, R. S., Hoefs, J., and Wedepohl, K. H., 1987. Stable isotope $(\mathrm{O}, \mathrm{H}, \mathrm{S})$ relationships in Tertiary basalts and their mantle xenoliths from the Northern Hessian Depression, W. Germany. Contrib. Mineral. Petrol., 95:350-369.

Haughton, D. R., Roeder, P., and Skinner, B. J., 1974. Solubility of sulfur in mafic magmas. Econ. Geol., 69:451-467.

Hubberten, H. W., 1983. Sulfur content and sulfur isotopes of basalts from the Costa Rica Rift (Hole 504B, DSDP Legs 69 and 70). In Honnorez, J., Von Herzen, R. P., et al., Init. Repts. DSDP,70: Washington (U.S. Govt. Printing Office), 629-635.

Katsura, T., and Nagashima, S., 1974. Solubility of sulfur in some magmas at 1 atmosphere. Geochim. Cosmochim. Acta., 38:517531 .

Kempton, P. D., and Hawkesworth, C. J., 1988. The Nd, Sr, and Pb isotopic composition of gabbros from Layer 3 of the oceanic crust, ODP Leg 118, Hole 735B. Geol. Soc. Am. Abstr. Programs, 20:158. (Abstract)

Kissin, S. A., and Scott, S. D., 1982. Phase relations involving pyrrhotite below $350^{\circ} \mathrm{C}$. Econ. Geol., 77:1739-1754.

Krouse, H. R., Brown, H. M., and Farquharson, R. B., 1977. Sulfur isotope compositions of sulfides and sulfates, DSDP Leg 37. Can. J. Earth Sci., 14:787-793.

Mathez, E. A., 1976. Sulfur solubility and magmatic sulfides in submarine basalt glass. J. Geophys. Res., 81:4269-4276.

Naldrett, A. J., 1981. Nickel sulfide deposits: classification, composition, and genesis. In Skinner, B. J. (Ed.), Economic Geology 75th Anniversary Volume: El Paso (Econ. Geol.), 485-627.

Ohmoto, H., and Rye, R.O., 1979. Isotopes of sulfur and carbon. In Barnes, H. L. (Ed.), Geochemistry of Hydrothermal Ore Deposits: New York (Wiley), 509-567.

Pasteris, J. D., 1984. Further interpretation of the Cu-Fe-Ni sulfide mineralization in the Duluth Complex, northeastern Minnesota. Can. Mineral., 22:39-53.

1985. Relationships between temperature and oxygen fugacity among $\mathrm{Fe}$-Ti oxides in two regions of the Duluth Complex. Can. Mineral., 23:111-127.

Puchelt, H., and Hubberten, H. W., 1979. Preliminary results of sulfur isotope investigations on DSDP cores from Legs 52 and 53. In Donnelly, T., Francheteau, J., Bryan, W., Robinson, P., Flower, M., Salisbury, M., et al., Init. Repts. DSDP, 51-53 (Pt. 2): Washington (U.S. Govt. Printing Office), 1145-1148.

Rees, C. E., Jenkins, W. J., and Monster, J., 1978. The sulphur isotopic composition of ocean water sulphate. Geochim. Cosmochim. Acta, 42:377-381.

Sakai, H., DesMarais, D. J., Ueda, A., and Moore, J. G., 1984. Concentrations and isotope ratios of carbon, nitrogen, and sulfur in ocean-floor basalts. Geochim. Cosmochim. Acta., 48:24332441.

Sasaki, A., 1969a. Sulfur isotope variation in Skaergaard rocks. Geol. Soc. Am. Spec. Pap., 121:263-264. (Abstract)

$1969 \mathrm{~b}$. Sulphur isotope study of the Muskox intrusion, district of Mackenzie. Geol. Surv. Can. Pap., 68-46:1-68.

Sasaki, A., and Ishihara, S., 1979. Sulfur isotopic composition of the magnetite-series and ilmenite series granitoids in Japan. Contrib. Mineral. Petrol., 68:107-115. 
Shanks, W. C. III, and Seyfried, W. E., Jr., 1987. Stable isotope studies of vent fluids and chimney minerals, southern Juan de Fuca Ridge: sodium metasomatism and seawater sulfate reduction. $J$. Geophys. Res., 92:11387-11399.

Shima, M., Gross, W. H., and Thode, H. G., 1963. Sulfur isotope abundances in basic sills, differentiated granites, and meteorites. J. Geophys. Res., 68:2835-2847.

Shipboard Scientific Party, 1989. Site 735. In Robinson, P. T., Von Herzen, R. P., et al., Proc. ODP, Init. Repts., 118: College Station, TX (Ocean Drilling Program).

Staudigel, H., Hart, S. R., Schmincke, H. U., and Smith, B. M., 1989. Cretaceous ocean crust at DSDP Sites 417 and 418: Carbon uptake from weathering vs. loss by magmatic outgassing. Geochim Cosmochim Acta, 53:3091-3094.

Thode, H. G., Dunford, H. B., and Shima, M., 1962. Sulfur isotope abundances in rocks of the Sudbury district and their geological significance. Econ Geol., 57:565-578.

Toulmin, P., and Barton, P. B., 1964. A thermodynamic study of pyrite and pyrrhotite. Geochim. Cosmochim. Acta 28:641-671.
Ueda, A., and Sakai, H., 1984. Sulfur isotope study of Quaternary volcanic rocks from the Japanese Islands Arc. Geochim. Cosmochim. Acta, 48:1837-1848.

Uyama, F., Chiba, H., Kusakabe, M. and Sakai, H., 1985. Sulfur isotope exchange reactions in the aqueous system: thiosulfatesulfide-sulfate at hydrothermal temperature. Geochem. J., 19:301315.

Woodhead, J. D., Harmon, R. S., and Fraser, D. G., 1987. O, S, Sr, and $\mathrm{Pb}$ isotope variations in volcanic rocks from the northern Mariana Islands: implications for crustal recycling in intra-oceanic arcs. Earth Planet. Sci. Lett.:, 83:39-52.

Date of initial receipt: 29 June 1989

Date of acceptance: 26 June 1990

Ms 118B-155 